URSZULA KOSIŃSKA

Uniwersytet Warszawski

\title{
STOSUNKI AUGUSTA II Z ROSJĄ W LATACH 1730-POCZĄTEK 1733 W ŚWIETLE RELACJI SASKIEGO POSŁA W MOSKWIE I PETERSBURGU JEANA LE FORTA*
}

U schyłku panowania Augusta II leitmotivem polityki starzejącego się króla stało się zapewnienie synowi Fryderykowi Augustowi korony polskiej. Kontynuacja unii polsko-saskiej była konieczna, aby Saksonia zachowała szansę na odegranie znaczącej roli w Europie, by mogła ubiegać się w przyszłości o udział w podziale spadku po austriackich Habsburgach i by nie została zdominowana przez swego największego wroga Brandenburgię-Prusy. Jest kwestią znaną od dawna, że o zagwarantowaniu synowi polskiego tronu August II marzył od początku panowania ${ }^{1}$. Perturbacje wojny północnej, a także dominująca osobowość królewskiego ministra Jakuba Henryka von Flemminga sprawiły jednak, że co najmniej od $1714 \mathrm{r}$. w saskim gabinecie obowiązywała strategia, by odrzucić pomysły o wprowadzaniu sukcesji drogą zamachu stanu, tłumić w zarodku pogłoski o dynastycznych planach Wettyna i nie liczyć na pomoc państw ościennych. Zdobywając społeczne poparcie w Polsce, należało czekać cierpliwie na bezkrólewie, licząc na to, iż syn królewski stanie się dla polskiej szlachty jedynym naturalnym kandydatem. Fryderykowi $\mathrm{Au}-$ gustowi zagrozić mógł jednak Stanisław Leszczyński, niefortunny król z czasów wojny północnej, a od 1725 r. teść Ludwika XV, lub inny kandydat poparty przez ościenne mocarstwa. Od połowy lat dwudziestych starzejący się i coraz bardziej schorowany August II podjął za radą części

\footnotetext{
* Niniejszy artykuł jest uzupełnioną i poprawioną wersją nieopublikowanego referatu wygłoszonego na Międzynarodowym Kongresie Badaczy Wieku Osiemnastego, który odbył się we Wrocławiu w październiku 2006 r.

${ }^{1}$ Potwierdziły to ostatnio badania Jacka Burdowicza-Nowickiego, Piotr I, August II i Rzeczpospolita (1697-1706), Kraków 2010, m.in. s. 141-142, 151, 160, 186, 594-597, 733.
} 
ministrów rywalizujących z Flemmingiem starania o dyplomatyczne przygotowanie sukcesji syna w Polsce ${ }^{2}$.

W początku lat trzydziestych Drezno zdawało już sobie sprawę, że zostało niewiele czasu, by znaleźć sojusznika, który wesprze królewskie aspiracje Wettynów, gdy w Polsce nastanie bezkrólewie. Na poparcie Austrii, tradycyjnego saskiego alianta, trudno było liczyć. Na przeszkodzie stały saskie roszczenia do sukcesji austriackiej i otwarta odmowa Drezna w 1732 r. uznania sankcji pragmatycznej. Fiaskiem zakończyły się tė̇ próby z lat 1728-1730 oparcia polityki saskiej na sojuszu z Prusami. Pod pozorami familiarności „Patrona” i „Compatrona” w kręgu Bractwa Wrogów Wstrzemięźliwości kryła się stała rywalizacja o wpływy w Rzeszy Niemieckiej i pruskie zapędy aneksjonistyczne wobec Rzeczypospolitej. Z Rosją, z którą utrzymywany był sojusz bazujący na traktacie narewskim z 1704 r., zachowywano pozornie dobre stosunki. Jednakże Rosja pragnęła utrzymać kontrolę nad Rzecząpospolitą jako państwem buforowym, zabezpieczającym ją przed ewentualną agresją, a zarazem stanowiącą dogodny korytarz łączący państwo carów z Europą. Dlatego z niechęcią spoglądała na próby jakiejkolwiek zmiany ustrojowego status quo nad Wisłą, a zwłaszcza osadzenia tu jakiejkolwiek dynastii. Utrzymanie Rzeczypospolitej w stanie permanentnej słabości było też warunkiem niezbędnym, by państwo carów mogło „skonsumować” zdobycze z wojny północnej: Inflanty i Kurlandię. Po śmierci Piotra I August II starał się wykorzystać względne osłabienie Rosji pod rządami Katarzyny I i Piotra II i przejąć utraconą kontrolę nad kurlandzkim lennem oraz doprowadzić do aliansu dynastycznego z Domem Romanowów. Nie uzyskał jednak żadnych realnych korzyści. Próba przestawienia polityki dworu drezdeńskiego na tory profrancuskie, choć spektakularna i prowadząca do widocznego zaostrzenia stosunków z Wiedniem, też nie zakończyła się zawarciem realnego sojuszu. Relacje z Wielką Brytanią czy Szwecją nie miały w ówczesnym układzie sił większego znaczenia. Panowało powszechne przekonanie, że w ostatecznej rozgrywce o tron polski najbardziej liczyć się będzie stanowisko Rosji, która po wstąpieniu w 1730 r. na tron Anny Iwanowny wyraźnie wracała na tory polityki imperialnej wytyczone przez Piotra Wielkiego ${ }^{3}$.

${ }^{2}$ Polityce dynastycznej Augusta II poświęciliśmy niedawno artykuł August II $i$ królewicz Fryderyk August w latach 1725-1729 a problem elekcji vivente rege, KH 119, 2012, 2, s. 305-321 oraz znaczne partie książki August II w poszukiwaniu sojusznika. Między aliansem wiedeńskim i hanowerskim (1725-1730), Warszawa 2012.

${ }^{3}$ Stosunki sasko-austriackie i sasko-pruskie w tym okresie najlepiej opisuje: A. Philipp, August der Starke und die pragmatische Sanktion, Leipzig 1908, Leipziger Historische Abchandlungen, t. 4; por. też J. G. Droysen, Geschichte der preussischen Politik, t. 4 , 
O działaniach dyplomacji Augusta II w Rosji między wstąpieniem na tron rosyjski Anny Iwanowny w lutym 1730 r. a początkiem bezkrólewia w Polsce w lutym 1733 wiadomo stosunkowo niewiele. Dlatego prześledzenie, jak wyglądały jej działania na kierunku rosyjskim w okresie, gdy dwór saski coraz intensywniej zaczął przygotowywać się do przyszłej elekcji w Polsce, wydaje się jednym z bardzo ważnych i interesujących zadań badawczych, tym bardziej, że brak szczegółowych, monograficznych opracowań tematu. Stare prace Siergieja Sołowjowa (Sergej Mihajlovič Solov'ev) czy Władimira Gerjego (Vladimir Ivanovič Ger'e (Guerrier)) w niewielkim stopniu uwzględniają działania dyplomacji saskiej w Petersburgu. Podstawowym opracowaniem tematu pozostaje wstępny rozdział pracy Rudolfa Beyricha czy niewielkie fragmenty dysertacji Klauspetera Strohma ${ }^{4}$. Z wydawnictw źródłowych dysponujemy jedynie wydanymi przez Ernsta Hermanna fragmentami raportów posła saskiego w Rosji Jeana Le Forta. Tymczasem to, co wydano, to jedynie znikomy procent oryginalnych relacji saskich z Rosji, nie sięgający, jak można szacować, nawet 2-3\% zasobów ${ }^{5}$. $\mathrm{W}$ pewnym stopniu uzupełniają je relacje francuskie i angielskie wydane w innych tomach tego wydawnictwa (obficie spożytkowane m.in. przez Emanuela Rostworowskiego), ale nie mogą one stanowić dobrego źródła do poznania celów dworu drezdeńskiego ${ }^{6}$. Po Hermannie jedynie Beyrich i Strohm korzystali z oryginałów korespondencji saskiej z Petersburga z lat 1732-1733, trudno jednak uznać, by wyczerpali materiał zawarty w źródłach. Celem niniejszego artykułu jest ukazanie, na podstawie materiałów Sächsisches Hauptstaatsarchiv w Dreźnie, jednego z problemów stosunków sasko-rosyjskich, tj. rokowań o odnowienie sojuszu i uzyskanie od Rosji gwarancji dla saskiej sukcesji w Polsce.

cz. 3, Leipzig 1869; P. Haake, La Société des antisobres, „Neues Archiv für Sächsische Geschichte und Altertumskunde", t. 21, 1900, s. 241-254; rokowania Francji z Augustem II opracował E. Rostworowski, 0 polska koronę. Polityka Francji w latach 1725-1733, Wrocław 1958; pewne uzupełnienia i korekty (w oparciu o źródła saskie): U. Kosińska, Polityka zagraniczna Augusta II w ostatnich latach jego panowania - rozważania nad książka Emmanuela Rostworowskeigo „O polska koronę, w: W kręgu badaczy dziejów politycznych XVIII wieku. Feldman, Rostworowski, Michalski, red. Z. Zielińska, W. Kriegseisen, Warszawa 2010, s. 45-56; ostatnio o stosunkach z Austrią, Prusami, Francją i Rosją w latach 1725-1730, eadem, August II w poszukiwaniu sojusznika.

${ }^{4}$ S. Solov'ev, Istoriâ Rossii s drevnejših vremen, t. 18-20, Moskva 1883 (korzystam z wydania Moskva 2002-2003); V. Ger'e, Bor'ba za pol'skij prestol v 1733 godu, Moskva 1862; R. Beyrich, Kursachsen und die polnische Thronfolge 1733-1736, Leipzig 1913, Leipziger Historische Abhandlungen, 36; i K. Strohm, Die kurländische Frage (1700-1736): Eine Studie zur Mächtepolitik im Ancien Régime, Berlin 1999.

${ }^{5}$ SIRIO, t. 3 i 5, S. Peterburg 1868 i 1870.

${ }^{6}$ SIRIO 66 i 81, S. Peterburg 1889 i 1892; E. Rostworowski, op. cit. 
W czasach Piotra II (1727-styczeń 1730) stosunki na linii DreznoWarszawa-Moskwa przedstawiały się wyjątkowo jałowo. Rządy małoletniego Piotra II, walki koterii dworskich o wpływ na monarchę i związane z nimi osłabienie Rosji nie sprzyjały realizacji jakichkolwiek ambitnych koncepcji politycznych ${ }^{7}$. Wraz z wstąpieniem Anny Iwanowny na tron rosyjski w lutym 1730 r. do władzy w Rosji doszła nowa ekipa rządząca. Początkowo August II wiązał swe nadzieje z wpływami tzw. fakcji staroruskiej, licząc na jej antycesarskie oraz antypruskie resentymenty oraz utrzymanie korzystnego dla Polski i Saksonii kursu niemieszania się Rosji w sprawy ogólnoeuropejskie ${ }^{8}$. W ciągu pierwszych miesięcy panowania Anny fakcja ta została jednak wyeliminowana z gry politycznej. Wkrótce możliwości działań króla polskiego na tym kierunku zredukowały się do starań o pośrednictwo ostatniego wpływowego „starorosjanina”, generalnego prokuratora Pawła Jagużyńskiego (Pavel Ivanovič Âgužinskij), określanego jako „przyjaciel króla polskiego” i „zaprzysięgły wróg Prusaków"9. Faktycznym kierownikiem rosyjskiej dyplomacji pozostał jednak Heinrich Johann Ostermann. Jego wpływy wraz z wstąpieniem Anny na tron zaczęły szybko rosnąć. W Dreźnie postrzegano go jako przychylnego Austrii i zarazem nieprzekupnego. Wobec narastającego od 1729 r. oziębienia między Saksonią a Austrią (wynikającego z odmowy Augusta II uznania sankcji pragmatycznej, a Karola VI dania gwarancji poparcia elektorowicza saskiego $\mathrm{w}$ walce o tron polski w przyszłym bezkrólewiu) szanse wywarcia wpływu na decyzje filoaustriackiego wicekanclerza były niewielkie ${ }^{10}$. Szczególną uwagę zwrócono na nowych faworytów carycy, Kurlandczyków - Ernesta Jana Birona

${ }^{7}$ U. Kosińska, August II w poszukiwaniu sojusznika, s. 500-508; I. V. Kurukin, Époha „dvorskih bur'”. Očerki političeskoj istorii poslepetrovskoj Rossii, Râzan' 2003, s. 144-154.

${ }^{8}$ I.V. Kurukin, op. cit., s. 179, 225-227; „Les Russes disent à cela: que nous servi l'alliance de l'Empereur? À sortir nos troupes de notre pays pour garder les frontières d'Hongrie, comme on l'avoit projeté. L'on n'aura pas assez de confiance en nous pour nous porter autrement. Nous ne tirons aucun avantage de cette alliance que de ruiner nos troupes et les exposer à ne jamais revoir leur patrie. Cette alliance est bonne en cas de rupture avec les Turcs. Quant à la Pologne, elle ne sauroit qu'être unie avec nous. Il faudra bien qu'elle nous suive et allors la cour de Prusse aura beau jeu", Jean Le Fort (dalej: LF) do Augusta II (dalej: A II), 2 II 1730, Sächsische Hauptstaatsarchiv Dresden, Geheimes Kabinett, Location 3023/7 Sachen mit dem moscowitischen Hof. Des Legations Raths Le Fort Negociation an denselben. Anno 1730 (I-V), vol. XIV (dalej: SHAD, Loc. 3023/7), k. 39v-40; LF do A II, 6 i 9 II 1730, ibidem, k. 54 i 55v; por. U. Kosińska, August II w poszukiwaniu sojusznika, s. 511.

${ }_{9}^{9}$ LF do A II, 8 VI 1730, SHAD, Loc. 3023/8 (Sachen mit dem Moscovitischen Hofe. Des Legations Raths und envoyé Le Fort Negotiation an denselben. Anno 1730 (VI-XII), vol. XV), k. 9v.

${ }^{10}$ „Je me fie beaucoup sur les sentiments de probité d'Ostermann. Cette grande machine en partie roule sur lui, mais seul incorruptible", LF do A II, 2 II 1730, SHAD, 
i trzech braci Löwenwoldów: marszałka dworu Karla Reinholda, koniuszego Karla Gustawa i Fryderyka Kazimierza. Birona oceniano jako życzliwego Augustowi II, choć starającego się nie narażać ani fakcji starorosyjskiej, ani cudzoziemskiej ${ }^{11}$. Löwenwoldowie okazali się natomiast szczególnymi rzecznikami zacieśnienia związków rosyjsko-pruskich, co wobec narastającego już od końca 1729 r. oziębienia na linii Drezno-Berlin nie wróżyło dobrze. Drezno szybko dostrzegło niebezpieczeństwo wzrostu wpływów Wiednia i Berlina w Moskwie, wynikające zarówno z politycznych sympatii nowej ekipy, jak i wzmożonej akcji dyplomatycznej państw zainteresowanych, które rychło wyczuły sprzyjającą im koniunkturę i przeznaczyły znaczne środki na działania w Moskwie ${ }^{12}$.

W tej nowej konstelacji Augustowi II groziła całkowita marginalizacja. Jego działania w Moskwie w 1730 r. były jednak mało aktywne i skupiały się na miałkich kwestiach wymiany deklaracji przyjaźni i prezentów ${ }^{13}$. Był to czas, gdy dwór saski zaczął być wstrząsany walkami o władzę między fakcją niemiecką (Ernsta Christopha Manteuffla i Augusta Christopha Wackerbartha), głoszącą potrzebę zachowania dobrych stosunków z Austrią i trzymania się zawartego w 1728 r. sojuszu z Prusami, a koterią Karla Heinricha von Hoyma i François Josepha Eleazara Wicardela de Fleury, dążącą do wywrócenia dotychczasowych układów i antypragmatycznego zbliżenia z Francją. W sierpniu $1730 \mathrm{r}$. odwołano z funkcji kierownika polityki zagranicznej Saksonii Manteuffla, zastępując go de Fleurym, co za granicą od razu odczytano jako oznakę zmiany pryncypiów saskich na antycesarskie i profrancuskie $^{14}$.

Loc. 3023/7, k. 53; I.V. Kurukin, op. cit., s. 227; o oziębieniu sasko-austriackim, U. Kosińska, August II w poszukiwaniu sojusznika, s. 381-386.

${ }^{11}$ LF do A II, 16 X 1730, SIRIO 5, s. 385-386; F.J. Wicardel de Fleury do LF, 19 X, 9 XI 1730, SHAD, Loc. 3361/3 (Depeschen aus und nach Moscau, 1730), k. 55v i 63v; LF do A II, 18 IX 1730, SHAD, Loc. 3023/8, k. 174v-175. Wkrótce Wiedeń zaproponował Bironowi tytuł hrabiowski i przekazał portret garnirowany brylantami; G. A. Nekrasov, Rol' Rossii v evropejskoj meždunarodnoj politike. 1725-1739 gg., Moskva 1976, s. 193.

${ }^{12} \mathrm{Na}$ wieść o wyniesieniu Anny Iwanowny Austria od razu zadeklarowała gotowość odnowienia z carycą przyjaźni. Prusy zareagowały radością, wyrażając przekonanie i nadzieję, że od tej pory Rosja nie będzie musiała oglądać się na Polskę w sprawie Kurlandii, S.M. Solov'ev, op. cit., t. 19, s. 355; LF do A II, 8 V 1730, SIRIO 5, s. 379-380; LF do A II, 18 IX 1730, SHAD, Loc. 3023/8, k. 172-173.

${ }^{13}$ E. Ch. Manteuffel i Fleury do LF, 9 III 1730, SHAD, Loc. 3362/9 (Ordres du roi à Mr. Le Fort à la cour de Russie de l'an 1726 jusqu'à l'an 32), posiedzenie Geheimes Consilium w tej sprawie już 2 III 1730, SHAD, Loc. 3023/7, k. 50-50v; instrukcje w tych materiach: Manteuffel do LF, 14 III, 10 VII, 15 VII 1730 i Fleury do LF, 15 VIII 1730, 8 X 1730, SHAD, Loc. 3361/3, k. 5-6v, 9, 24, 29-30, 46-47; por. też U. Kosińska, August II w poszukiwaniu sojusznika, s. 511-512.

${ }^{14}$ LF do A II, 2 X 1730, SHAD, Loc. 3023/8, k. 200-200v; U. Kosińska, August II w poszukiwaniu sojusznika, s. 431-433, 436-438. 
Nie jest chyba przypadkiem, że gdy latem 1730 r. do Moskwy dotarły informacje o oddalaniu się Augusta II od Austrii i Prus i intensyfikacji rozmów z Francją, odczytano to jako groźbę zerwania sojuszu z Rosją. Od lat zresztą jakakolwiek aktywność Augusta II na niwie międzynarodowej wzmagała uwagę Rosji. I choć pewna skłonność do zacieśnienia stosunków austro-prusko-rosyjskich zauważalna była znacznie wcześniej, fakt ten stał się - jak się zdaje - impulsem do intensyfikacji rozmów między obydwoma dworami cesarskimi na temat konieczności ustalenia wspólnego stanowiska w sprawie polskiej ${ }^{15}$.

Tymczasem we wrześniu 1730 r. Ostermann wystąpił wobec Le Forta z propozycją odnowienia dawnego aliansu przyjaźni z Augustem II we współpracy z cesarzem ${ }^{16}$. Jednocześnie z kręgów zbliżonych do rywalizującego z wicekanclerzem Jagużyńskiego zaczęto dawać sygnały, że jest szansa na stworzenie nowej ligi, ale w oderwaniu od aliansu wiedeńskiego ${ }^{17}$. Mimo tej rozbieżności stanowisk „matadorów” dworu rosyjskiego saski poseł w Rosji optymistycznie zapewnił Augusta II, że ma on okazję odnowić przyjaźń z Rosją, jeśli zdecyduje się, wzorem sąsiadów, przeznaczyć znaczne środki finansowe na pozyskanie w Rosji osób wpływowych ${ }^{18}$. Odnawianie traktatów przyjaźni, tak częste w przypadku zmiany na tronie, daje zawsze pewną szansę na uzyskanie od strony bardziej zainteresowanej korzystniejszych niż dotąd zapisów. Jednak próby Le Forta wydobycia od Ostermanna ewentualnych warunków odnowienia traktatów zakończyły się niepowodzeniem. Minister zbywał posła frazesami o potrzebie zaufania i konieczności włączenia Austrii

${ }^{15}$ Rozmowy rosyjsko-austriackie o odnowienie sojuszu z 1726 r. z włączeniem doń strony pruskiej toczyły się co najmniej od 1729 r. Wymagają one odrębnego przebadania, już teraz można jednak podkreślić, że od początku ich istotnym elementem była kwestia sukcesji polskiej, Istoričeskoe izvestie ob izbranii na pol'skij prestol korolâ Avgusta III v 1733 godu, [wyd. N. N. Bantyš-Kamenskij] „Russkij Vestnik” 1841, nr 4, s. 126-127; V. Ger'e, op. cit., s. 45-49; S.G. Nelipovič, Soûz dvuglavnyh orlov. Russko-avstrijskij voennyj al'âns vtoroj četverti XVIII v., Moskva 2010, s. 92-93; U. Kosińska, August II w poszukiwaniu sojusznika, s. 510.

${ }^{16}$ U. Kosińska, August II w poszukiwaniu sojusznika, s. 513; ibidem w przyp. 318 cytat $\mathrm{z}$ raportu LF do A II, 11 IX 1730, SHAD, Loc. 3023/8, k. 151v-152.

17 „Osterman m'a répondu, qu'il espéroit, que les griefs que pouvoit avoir VM [Votre Majesté] contre la cour impériale seroient sans doute pas assez importants pour donner lieu à une mésintelligence formelle, d'autant plus qu'il croyoit de l'intérêt de VM de se lier étroitement avec la czarienne et avec l'empereur", LF do A II, 16 X 1730, SHAD, Loc. 3023/8, k. 222-222v.

18 „l'on ne sauroit dire que depuis dix ans le roi de Pologne ait déboursé un sol ni pour se faire des créatures ni pour être sur les avis, mais je sais ce qu'il m'en coute pour les présents d'attention à chaque fête, car rien ne se fait que par là", LF do Fleury'ego, 25 IX 1730, SHAD, Loc. 3023/8, k. 190v-191; podobnie LF do A II, 2 X 1730, ibidem, k. 200v-201. 
do układu ${ }^{19}$. Jagużyński, będący w konflikcie z Ostermannem, podważał te deklaracje i twierdził, że wicekanclerz utracił już zaufanie carycy i jego obietnice są bez pokrycia. Wyjawił też, że za poprzednich rządów Ostermann podpisał z Prusami traktat, który można uznać za sprzeczny z interesem króla polskiego ${ }^{20}$. Faworyt Anny, Biron, tłumaczył się natomiast, że nie będąc ministrem, nie ma możliwości mieszania się do spraw państwowych, może najwyżej coś zasugerować carycy i dać tym dowody gorliwości swemu suwerenowi, królowi polskiemu ${ }^{21}$.

W odpowiedzi na propozycję odnowienia traktatu przyjaźni Drezno zapewniło, że we wzajemnych stosunkach celem nadrzędnym pozostaje utrzymanie dotychczasowego sojuszu, a zmiana ministra spraw zagranicznych Saksonii nie oznacza zmiany pryncypiów ${ }^{22}$. Zapowiedź odnowienia traktatów sojuszniczych przyjęto jednak z rezerwą. Odpowiedziano, że warunkiem podstawowym byłoby dotrzymanie dotychczasowych układów przez Rosję i zgodnie z nimi powstrzymanie się od zawierania za plecami króla polskiego nowych porozumień z innymi państwami. Była to niewątpliwie aluzja do traktatu rosyjsko-pruskiego z 9/12 września 1729 r. - o odnowieniu tego aliansu 30 września 1730 r. dwór polski jeszcze najprawdopodobniej nie wiedział ${ }^{23}$. Drezno nie dało więc wiary propozycjom Ostermanna, ale i nie okazało nimi większego zainteresowania.

${ }^{19}$ LF do A II, 6 XI 1730, ibidem, k. 255-256v.

${ }^{20}$ „Jagouzinski me dit, qu'Ostermann n'étoit ni en crédit ni en pouvoir de prendre quelque chose sur lui. Qu'il nous promettoit monts et merveilles qui n'auroient aucune suite. Qu'il se pouvoit que du règne précédente ou eut pris quelques engagements contraires aux vues de VM. Que la chose étoit à redresser et qu'il étoit trop bon serviteur de VM pour n'y pas coopérer de tout son pouvoir, si VM avoit confiance en lui. Qu'il me l'avoit dit il y a longtemps comme aussi j'en ai fait mon rapport que la conjoncture étoit favorable pour se lier avec la cour czarienne sur les intérêts de la Pologne et que si VM vouloit la ménager, la Czarienne, qui aimoit VM lui pouvoit donner des marques du cas, qu'elle fait de sa personne. Qu'un système pouvoit bientôt être formé", LF do A II, 6 XI 1730, SHAD, Loc. 3023/8, k. 257-257v; o tym, że 19/30 września 1730 r. podpisano z Prusami kolejny traktat, 19 października ratyfikowany przez carycę, Jagużyński się nawet nie zająknął.

${ }^{21}$ LF do A II, 6 XI 1730, SHAD, Loc. 3023/8, k. 258.

${ }^{22}$ U. Kosińska, August II w poszukiwaniu sojusznika, s. 513.

${ }^{23}$ Le Fort miał w imieniu króla zapewnić: „de la disposition où il [Auguste II] est d'apprendre avec plaisir ce qui seroit practicable pour en venir à ce que Mr le vice-chancelier [Ostermann] propose: de consolider et de perpétuer l'amitié et la bonne intelligence qui subsistent. Sa Majesté [dalej: SM] est persuadé, que pour parvenir au but d'un si louable dessein, il faut nécessairement commencer par s'abstenir de prendre aucun engagement avec d'autres amis, qui puissent, l'un ou l'autre, entraîner à blesser essentiellement les intérêts réciproques des deux cours", Fleury do LF, $9 \mathrm{X}$ 1730, SHAD, Loc. 3362/9; podobnie [A II] do [Anny Iwanowny], [październik 1730] SHAD, Loc. $3361 / 3$, k. 51-52. 
16 listopada Fleury poinformował Le Forta, że nie ma potrzeby wysyłania mu nowych instrukcji ${ }^{24}$.

Jak się zdaje, także ze strony rosyjskiej brakło rzeczywistej intencji doprowadzenia rokowań z Dreznem do skutku. Była to ewidentnie gra obliczona na zakamuflowanie prowadzonych równolegle negocjacji rosyjskich z Austrią i Prusami. Pierwszy ich etap zakończył się 19/30 września odnowieniem traktatu rosyjsko-pruskiego z 1729 r. Powtórzono w nim tajny zapis o współpracy w kwestii przyszłej obsady polskiego tronu i niedopuszczenia do przekazania go przez Augusta II synowi vivente principe ani do elekcji Leszczyńskiego. Dodano też tajną deklarację o współpracy w sprawie polskich dysydentów (ewangelików i prawosławnych) ${ }^{25}$. Prośby Le Forta, gdy już dowiedział się o odnowieniu traktatu, by ujawniono jego treść, zbywane były ogólnikami przez wszystkich ministrów rosyjskich ${ }^{26}$.Znacznie później, gdy okazało się, że Drezno i tak sporo wie o treści traktatu, zwłaszcza w sprawie dysydenckiej ${ }^{27}$, Biron oświadczył (niezgodnie z prawdą), że już w układzie z 1729 r. znalazły się zapisy o gotowości wprowadzenia do Polski wojsk dla podtrzymania praw Cerkwi prawosławnej i dysydentów oraz poparciu kandydatury Piasta do tronu polskiego ${ }^{28}$. Cały czas też - wbrew faktom - wypierano się ratyfikacji nowego układu, która nastąpiła przecież 19/30 października 1730 r. ${ }^{29}$

${ }^{24}$ U. Kosińska, August II w poszukiwaniu sojusznika, s. 513 (Fleury do LF, 16 XI 1730, SHAD, Loc. 3361/3, k. 68).

${ }^{25}$ Sobranie traktatov i konvencij, zaklûčennyh Rossiej s inostrannymi deržavami, wyd. F.F. Martens, t. 5: Traktaty s Germaniej. 1656-1762, S. Peterburg 1880, s. 275-291; por. Preussens Staatsverträge aus der Regierungszeit König Friedrich Wilhelms I., wyd. V. Loewe, Leipzig 1913, Publikationen aus den königlischen preussischen Staatsarchiven, 87, s. 395-397; Sergej G. Nelipovič (op. cit., s. 94) myli się, jakoby traktat rosyjsko-pruski z 1730 r. (będący odnowieniem układu z 1729 r.) zawierał klauzulę otwarcie wykluczającą Wettyna od tronu polskiego; prawidłowo streszcza V.Ger'e, op. cit., s. 49-50; o powodach rezygnacji z podobnej klauzuli w traktacie z 1729 r., U. Kosińska, August II w poszukiwaniu sojusznika, s. 353-362.

${ }^{26}$ LF do A II, 30 X 1730, SHAD, Loc. 3023/8, k. 246.

${ }^{27}$ Fleury do LF, 26 I 1731, SHAD, Loc. 3361/4 (Depeschen aus und nach Moscau 1731), k. 8-8v.

${ }^{28}$ „de faire marcher les troupes, l'un pour soutenir les églises greques en Pologne, l'autre pour protéger les dissidents et que dans ce traité il devoit être stipulé que la succession future à la Couronne doit passer à un Piaste", LF do A II, 1 I 1731, SHAD, Loc. 3024/1 (Sachen mit dem moscovitischen Hofe. Le Fort Negotiation an denselben anno 1731, vol.XVI), k. 14. Tak w kwestii dysydenckiej, jak i poparcia Piasta Biron mijał się z prawdą. Być może miało to złagodzić złe wrażenie, jakie na saskim pośle musiał wywrzeć fakt podpisania traktatu (odnowienie dawnych klauzul brzmiało nieco mniej niekorzystnie niż podpisanie nowych). Nie można jednak wykluczyć, że faworyt carycy nie do końca orientował się w tajnikach rokowań prowadzonych przez Ostermanna.

${ }^{29}$ Sobranie traktatov, t. 5, s. 291; Preussens Staatsverträge, s. 395. 
Ostatecznie w 1730 r. rozmów o odnowienie sojuszu polsko-rosyjskiego nie podjęto. August II uznał, że nie ma podstaw do rozpoczynania jakichkolwiek negocjacji z Rosjanami, zwłaszcza trójstronnych, wobec pogłębiających się rozdźwięków między Dreznem a Wiedniem ${ }^{30}$. Dopiero wówczas do saskiego posła, wciąż przekonanego, że dwór rosyjski ma dobre intencje i chce wejść w negocjacje traktatowe ${ }^{31}$, zaczęło powoli docierać, iż nie ma na to szans. Wkrótce też otrzymał on ostre reprymendy z Drezna za zaniedbanie obowiązków i łatwowierność. Skrytykowano go, że będąc w centrum wydarzeń, nie poinformował o staraniach księcia portugalskiego Emanuela (de Bragança) o sukcesję polską, o rokowaniach Ostermanna z Austriakami i podpisaniu traktatu rosyjsko-pruskiego, a więc o sprawach o pierwszorzędnym znaczeniu ${ }^{32}$. Rozeszły się nawet pogłoski, że szykuje się odwołanie Le Forta z placówki ${ }^{33}$. Przy okazji Rosjanie dali saskiemu posłowi do zrozumienia, iż caryca doskonale orientuje się, na czym naprawdę zależy Augustowi II. Celem zasadniczym miał być - jak to nazwano - „interes” królewicza, czyli kwestia sukcesji w Polsce. Tego tematu Le Fort wówczas roztropnie nie podją ${ }^{34}$. Jego doniesienia o nieratyfikowaniu traktatu rosyjsko-pruskiego przyjęto w Dreźnie z wielkim zdziwieniem, zwłaszcza że miano wiarygodne informacje, iż ową ratyfikację przewiózł do Berlina przeniesiony z Warszawy nad Sprewę poseł Michaił Biestużew (Mihail Petrovič Bestužev-Rûmin). Le Forta spotkała po tym kolejna reprymenda za łatwowierność i bezkrytyczne powtarzanie, bez próby potwierdzania, deklaracji składanych przez Rosjan ${ }^{35}$.

${ }^{30}$ U. Kosińska, August II w poszukiwaniu sojusznika, s. 514; Fleury do Le Forta, 14 XII 1730, ibidem, k. 82v; potwierdzenie tego stanowiska idem ad eundem, 18 I 1731, SHAD, Loc. 3023/8, k. 387-387v.

31 „Je ne puis m'empêcher de témoigner à Votre Excellence la satisfaction que j'ai de voir présentement l'heureuse disposition de cette cour à l'égard de la nôtre et j'ose avancer que pour peu que SM veuille prêter la main, elle peut mettre à profit la situation présente", LF do Fleury'ego, 11 XII 1730, SHAD, Loc. 3023/8, k. 348.

${ }^{32}$ U. Kosińska, August II w poszukiwaniu sojusznika, s. 514 (Fleury do LF, 30 XI, 14 XII 1730, SHAD, Loc. 3361/3, k. 75-75v, 81-82, 88-88v); nb. angielski rezydent Claudius Rondeau donosił o zawarciu traktatu rosyjsko-pruskiego już we wrześniu 1730 r., SIRIO 66, s. 229, 246.

${ }^{33}$ Fleury do LF, 21 XII 1730, SHAD, Loc. 3361/3, k. 88-88v; Fleury do LF, 1 II 1731, SHAD, Loc. $3361 / 4, \mathrm{k} .14 \mathrm{v}$.

${ }^{34}$ „Que si c'est pour les intérêts de Sa Altesse le Prince Royal, il faut le mettre au fait, et qu'il rendra les services qui dépendront de lui. Qu'il en sera de même sur quelque autre matière, qui puisse se présenter, pourvu que ce soit un plan solide, stable, bien digéré, auquel on ne veuille plus retoucher", LF do Fleury'ego, 8 I 1731, SHAD, Loc. 3024/1, k. 32-32v.

${ }^{35}$ „Ce n'est pas par la faute de SM, que l'on a de la facilité, où vous êtes (et vous entre autres) de croire tous les avis que l'on débite sans approffondir d'où ils 
Po takich doświadczeniach August II uznał, że nie ma podstaw do rozpoczynania jakichkolwiek negocjacji z Rosją. Le Fort otrzymał rozkazy, by przestał nalegać na konfidencję, uruchomił własne źródła informacji i czekał na lepsze okoliczności, gdy caryca zacznie rządzić bardziej samodzielnie, okazując większą przychylność królowi polskiemu ${ }^{36}$. Napięcie we wzajemnych stosunkach doszło do tego poziomu, że w lutym $1731 \mathrm{r}$. w liście do Jagużyńskiego jeden z ministrów saskich (prawdopodobnie Fleury) ostrzegł, iż ratyfikacja traktatu rosyjsko-pruskiego zniszczy dobre stosunki Rosji z Polską. Zapowiedział też, że August II nie omieszka zażądać zerwania tego układu i caryca musi rozważyć, czy warto utrzymywać tak ścisły związek z Wiedniem i Berlinem ${ }^{37}$. Po tym liście rozmowy sasko-rosyjskie zostały de facto zamrożone. Biron i Jagużyński przestali udzielać Le Fortowi jakichkolwiek informacji. Drezno ponownie ostrzegło posła, by był ostrożniejszy i nie tak łatwowierny ${ }^{38}$.

Treść saskiej korespondencji z tego okresu świadczy nie tylko o oziębieniu stosunków z Rosją. Dowodzi także obniżenia się poziomu saskiej dyplomacji pod kierownictwem Wicardela de Fleury. Relacje Le Forta w $1731 \mathrm{r}$. zdominowały sprawy błahe, dotyczące aktorów, muzyków i prywatnych interesów handlowych ministrów saskich. Gdy okazało się, że i tą drogą nie udało się doprowadzić do ocieplenia stosunków, Fleury, który sam promował wiele z tych spraw, zwrócił w końcu Le Fortowi uwagę, iż okazuje tym kwestiom zainteresowanie nieproporcjonalne do roli,jaką odgrywająa

viennent. Permetez-mois de vous avertir que le principal devoir d'un ministre employé à une cour étrangère est de répandre de sa propre cour", Fleury do LF, 1 II 1731, SHAD, Loc. 3361/4, k. 14-14v.

${ }^{36}$ Fleury do LF, 18 I 1731, SHAD, Loc. 3023/8, k. 387-387v; „Il vaut mieux garder la silence et différer à s'expliquer que d'assurer ce qui n'est pas et s'exposer par-là à devoir changer de langage", Fleury do LF, 26 I 1731, SHAD, Loc. 3361/4, k. 8v; Fleury do LF, 15 II 1731, SHAD, Loc. 3361/4, k. 20-20v.

37 „SM ne s'omisera pas de proposer que l'on rompe ce traité. C'est une sage conseil dont SM Czarienne se sert pour les affaires secrètes à examiner, s'il convient de trouver des expédients pour déroger à quelques articles de ce traité qui printent[s!] SM Czarienne de la liberté de faire ce qui dépend d'elle pour assurer la continuation de l'amitié de quelqu'autre puissance. Enfin SM Czarienne seule peut savoir jusques-où elle est effectivement liée avec les cours de Vienne et de Berlin et s'il lui convient de renoncer à l'avantage de tout autre liaison pour s'en tenir rigorousement à celles-là", NN minister saski do Jagużyńskiego, 1 II 1731, SHAD, Loc. 3017/2 (Sachen mit dem Russischen Kayserlischen Hofe in verschiedenen Materien, 1730-1762), k. 12v-13; podobnie idem do Birona, ibidem, k. 15v-17.

38 „Il ne faut nullement presser ni se plaindre, mais je vous conseille à l'avenir d'être moins crédule. Il est indispensable de rendre un compte exacte de ce que l'on vous dit et de la manière dont vous repondez", Fleury do LF, 12 V 1731, SHAD, Loc. $3361 / 4$, k. 59-60v.

${ }^{39}$ Fleury do LF, 11 VIII 1731, SHAD, Loc. 3361/4, k. 103v; jedynym śladem większej aktywności dyplomacji saskiej w Moskwie w 1731 r.jest dość dwuznaczna, a słabo roz- 
Na zauważalną „pasywność” Drezna wobec Rosji w ciągu 1731 r. wpłynąć mogło także kilka innych czynników. Trzeba pamiętać, że właśnie rodził się promowany przez Ostermanna i fakcję Löwenwoldów wrogi królowi polskiemu sojusz „trzech czarnych orłów”. Już 7 listopada 1730 r. cesarski poseł Franz Karl von Mitrowitz Wratislaw przedstawił Ostermannowi propozycję zawarcia trójstronnego układu austro-rosyjsko-pruskiego w sprawie obsady polskiego tronu. Przyszli sygnatariusze poprzeć mieliby w bezkrólewiu jakiegoś kandydata piastowskiego (ale z bezwzględnym wykluczeniem Leszczyńskiego); kandydatura obca mogła być do przyjęcia tylko wówczas, gdyby stanowiła jedyną alternatywę dla Stanisława. 14 grudnia austriacki dyplomata zaproponował już konkretny projekt trójstronnej austro-rosyjsko-pruskiej konwencji w tej sprawie. Został on wstępnie aprobowany przez Annę Iwanowną 2/13 stycznia $1731 \mathrm{r}^{40}$

Tymczasem w Dreźnie rozmywała się perspektywa ewentualnej antypragmatycznej współpracy Saksonii z Francją. Dwór saski targany był pożerającymi jego uwagę walkami gabinetowymi. Ich efektem stała się dymisja czołowych orędowników opcji profrancuskiej: w marcu $1731 \mathrm{r}$. Hoyma, a w listopadzie Fleury'ego ${ }^{41}$. W Moskwie też toczyły się zacięte walki gabinetowe między fakcją „niemiecką” i starorosyjską, które pod koniec 1731 r. wygrali sprzyjający Austrii i Prusom „Niemcy”. Jagużyński został odsunięty i skazany na „honorowe zesłanie” do Berlina ${ }^{42}$. Jego upadek zmusił Drezno do zintensyfikowania (ograniczonych do tej pory) kontaktów ze zwycięskim Ostermannem i prób odzyskania przychylności Birona postrzeganego przez Drezno (mimo wielu zastrzeżeń do jego koniunkturalizmu i interesowności) jako jedyna osoba na dworze rosyjskim względnie życzliwa królowi polskiemu ${ }^{43}$. Fakty te zbiegły się w czasie z przejęciem w końcu 1731 r. kontroli nad dyplomacją saską (po odsunięciu Wicardela de Fleury) przez samego Augusta II.

poznana misja bratanka prymasowskiego Antoniego Potockiego, która miała najprawdopodobniej na celu rozerwanie zacieśniających się związków rosyjsko-austriackich i rosyjsko-pruskich w oparciu o kontakty z fakcją starorusów; na podstawie relacji francuskich i angielskich drukowanych w SIRIO 66 i 81 omówił ją E. Rostworowski (op. cit., s. 232-236), dotąd nie przebadano jednak gruntownie tego poselstwa.

${ }^{40}$ Istoričeskoe izvestie, s. 127-129; V. Ger'e, op. cit., s. 50-51; S. G. Nelipovič, op. cit., s. 93-94.

${ }^{41}$ U. Kosińska, August II w poszukiwaniu sojusznika, s. 436-441.

${ }^{42}$ SIRIO 5, s. 441; I.V. Kurukin, op. cit., s. 230.

${ }^{43}$ LF do A II, 26 XI 1731, SHAD, Loc. 3024/2 (Sachen mit dem Moscowitischen Hofe [--] Le Fort Negotiation an denselben anno 1731, vol. XVII), k. 198-200; idem ad eundem, 26 I 1732, SHAD, Loc. 3024/3 (Sachen mit dem Moscowitischen Hofe. Der Geheimer Rath und Envoyé Le Fort Negotiation an denselben anno 1732, vol. XVIII), k. $26 \mathrm{v}-28 \mathrm{v}$. 
Już pierwsza osobista instrukcja króla dla Le Forta pokazuje, że władca postawił na przywrócenie dobrych stosunków z Rosją. Utrzymanie sojuszu uznał za najważniejsze zadanie posła ${ }^{44}$. Tym razem to strona saska wyszła z inicjatywą wznowienia rozmów o odnowę traktatu przyjaźni. Można by sądzić, że powodem nagłej aktywności dyplomatycznej króla polskiego była dotychczasowa jałowość rokowań z Francją. Z treści korespondencji Le Forta z Augustem II wynika jednak, że chodziło przede wszystkim o rozerwanie związków Rosji z Austrią i Prusami, niebezpiecznych dla Saksonii zarówno z perspektywy szans na elekcję w Polsce, jak i walki o dominację w Rzeszy ${ }^{45}$. Jak się więc zdaje, to zmiany w Rosji i świadomość, że proniemieckie nastroje na dworze carów doprowadzić mogą do wzięcia Saksonii i Polski w kleszcze, uaktywniły politykę wschodnią dworu drezdeńskiego. Szczególny niepokój wzbudziło poselstwo K. G. Löwenwolde do Wiednia i Berlina. Gra toczyła się o jeszcze jedną stawkę. Była nią ręka czternastoletniej wówczas księżniczki meklemburskiej Elżbiety (zwanej w Rosji Anną Leopoldowną) siostrzenicy i prawdopodobnej następczyni Anny Iwanowny. Starało się o nią już wielu książąt, najusilniej jednak promowano w Rosji ożenek z którymś z książąt pruskich. Na taki mariaż nie wyrażały zgody inne państwa, zwłaszcza Austria, Anglia czy Rzeczpospolita, obawiające się zbytniego wzmocnienia Berlina ${ }^{46}$. W styczniu 1732 r. Le Fort zaproponował ostrożnie Bironowi wydanie księżniczki za krewniaka króla polskiego, czterdziestosiedmioletniego księcia Jana Adolfa Sachsen-Weißenfels ${ }^{47}$.W lutym saski dyplomata zasugerował, że jeśli imperatorowa zrezygnuje z księcia pruskiego, wówczas Drezno uzna to za dowód ze-

${ }^{44}$ Oto próbka stylu tej instrukcji: „Je savois ce qui peut affermir ou blesser l'union qui ce souhaitte d'entretenir sincèrement entre mon Royaume et la Russie. Que cet objet étant le principal qui doive m'occuper. [--] Puisque de mon côté je ne néglige rien de tout ce qui tend à conserver une parfaite harmonie. Vous pourrez aussi insinuer comme de vous-même à messieurs de Biron, d'Osterman et de Munich, que de quelles formalités que leur indigénat soit revêtu, ils ne peuvent jamais se flatter de gagner l'amitié des anciens Russes ni d'obtenir leur aprobation quelle circonspection et quelle sagesse qu'ils apportent à leur conduite, que par-là l'amitié d'un prince aussi voisin que je suis. Est ce qu'ils ont le plus à rechercher et que cette manière d'affermir le gouvernement et leur autorité particulière est d'autant plus sûre que convenant aux deux nations voisines [--] Vous ne devez pas témoigner avoir reçu aucuns ordres à cet égard ni affecter aucun empressement à les exécuter, mais comme vous continuerez à leur parler sur le ton que vous avez fait, la conversation vous conduira insensiblement à faire les réflexions que je vous suggére", A II do LF, 26 XII 1731, SHAD, Loc. $3362 / 9$.

${ }^{45}$ LF do A II, 12 II 1732, SHAD, Loc. 3024/3, k. 65.

${ }^{46}$ A II do LF, 2 II 1732, SHAD, Loc. 3362/9.

${ }^{47}$ E. Rostworowski, op. cit., s. 253; memoriał Le Forta dla Fleury'ego w tej sprawie, SIRIO 5, s. 447. 
rwania z opcją pruską. Biron zapowiedział, że może poprzeć projekt i niedwuznacznie dopominał się o „wdzięczność” ${ }^{48}$. Kilka dni później saski poseł, jakoby z własnej inicjatywy, zasugerował Augustowi II, iż nagrodą dla Birona za doprowadzenie małżeństwa do skutku mogłoby stać się księstwo kurlandzkie, „ów węzeł gordyjski” w stosunkach polsko-rosyjskich $^{49}$. Rosjanie poprosili Augusta II, aby podał swe warunki ${ }^{50}$. Drezno odpowiedziało jednak bardzo ostrożnie, pomne na rosyjskie zobowiązania traktatowe wobec Austrii i Prus. I choć Biron i Ostermann zapewniali w imieniu Anny, że nie wiążą jej w tym względzie żadne układy, Drezno reagowało na te deklaracje $\mathrm{z}$ rezerwą ${ }^{51}$.

Wkrótce w relacjach Le Forta znalazła się sugestia, że przeprowadzenie proponowanego aliansu dynastycznego pomogłoby sukcesji wettyńskiej w Polsce. Nie mamy pewności, czy był to własny pomysł saskiego przedstawiciela, czy też pewne sugestie $\mathrm{w}$ tej materii nie popłynęły $\mathrm{z}$ dworu rosyjskiego ${ }^{52}$. Jest jednak charakterystyczne, że pojawiły się one wówczas, gdy August II rzeczywiście postanowił wznowić rokowania z Rosjanami ${ }^{53}$. Dowodzi tego depesza dla Le Forta o charakterze instrukcji (,pro instructione”) z 9 kwietnia 1732 r. Pierwszym zadaniem dyplomaty miało być dyskretne (bez kompromitowania króla) zbadanie, czy dwór rosyjski rzeczywiście ma - jak mówi - wolne ręce, aby wejść w przyszłości w jakieś związki z królem polskim. Następnie zlecano posłowi opracowanie memoriału zawierającego saskie propozycje i przekazanie go na ręce Birona. Faworyta postrzegano jako człowieka, który dla

${ }^{48}$ SIRIO 5, s. 448-449; R. Beyrich, op. cit., s. 6; LF do A II, 12 II 1732, SHAD, Loc. 3024/3, k. 62, 69-73; Pani Le Fort do H. Brühla, ibidem, k. 75-76.

${ }^{49}$ „Si j'eus un plan à suivre et que je visé se que l'on ne donna pas dans celui que l'on se propose, je m'attecherois à flatter d'espérance de Biron d'un coté un duché de Courlande. Car c'est pourtant le nœud gordien, on tout aboutit. Je demande pardon à VM, le système est un peu outre. Une femme sonde et l'on pourroit à ce qu'il me paroît simuler un agrément en faveur de celui qui doit emporter celle qui succedera. Cet appas formeroit une union inséperable et l'on pouroit voir un jour-là les Prussiens baisser les ailes quant à présent la proposition paroît être gouté. Mais je ne crains rien tant qu'une bordée de gallions Prussiens qui sans contremine inonderoit les cœurs, si la mèche venoit à s'éventer", LF do A II, 19 II 1732, SHAD, Loc. 3024/3, k. 95-95v.

${ }^{50}$ LF do A II, 26 II 1732, SHAD, Loc. 3024/3, k. 102v.

${ }^{51}$ A II do LF, 12 III 1732, SHAD, Loc. 3362/9; LF do A II, 18 III, 8 IV 1732, SHAD, Loc. $3024 / 3$, k. 127-130, 186.

52 ,Je ne saurois parler de moi. Dans tel cas je me trouverois d'obligation à faire une dépense du diable et chère enragée pour mettre l'affaire en train. Et d'où prendre? Mais qui pourroit savoir si par cette alliance on ne pourroit assurer la Couronne à notre Prince Royal, supposé que l'on en fournisse le bien"; LF do [Brühla], 1 IV 1732, SHAD, Loc. 3024/3, k. 181-181v.

${ }^{53}$ J. A. Thioly do LF, 2 IV 1732, SHAD, Loc. 3362/9; sekretarz Walther do LF, 10 IV 1732, ibidem. 
swych ambicji i własnego wyniesienia gotów będzie, bardziej niż ktokolwiek inny, dogadać się z Augustem II i poprzeć plan małżeństwa ks. Jana Adolfa z księżniczką meklemburską. Dowodem skuteczności tego pośrednictwa miało być wysłanie przez carycę na dwór saski emisariusza upoważnionego do prowadzenia rokowań ${ }^{54}$. Projekt wspomnianego memoriału, który Le Fort powinien przekazać faworytowi w formie jakoby brulionowej i własnoręcznej, został opracowany już w Dreźnie. Jego sednem, obok licznych zastrzeżeń dotyczących utrzymania najgłębszego sekretu, a także sugestii nagrody za „dobre usługi”, była sprawa sukcesji polskiej. Zapewniano w nim, że Polska rządzona przez elektora saskiego jest sąsiadem bardzo korzystnym dla Rosji, a August II akceptuje obecną formę rządu Rosji i poprze z całych sił sukcesora na tron carów, jakiego wyznaczy imperatorowa. Argumentowano, że z oczywistych względów takich gwarancji nie może dać żaden Piast. W zamian oczekiwano, iż Anna poprze kandydaturę elektorowicza saskiego do korony polskiej ${ }^{55}$. Nadto Rosja zobowiązałaby się konsultować z królem polskim kandydata na męża dla Anny Leopoldowny i nie wybierać żadnego z silnych książąt niemieckich. Imię kandydata proponowanego przez Saksonię nie zostało w memoriale wymienione, ale oczywiste było, że chodzi o księcia Jana Adolfa. Drezno chciało też, aby to strona rosyjska wystąpiła formalnie jako inicjatorka układu i pierwsza odkryła karty, tj. podała warunki. Saski poseł miał zasugerować Bironowi, że pewnie zechce on figurować jako autor projektu i kierować rozmowami ${ }^{56}$.

Le Fort postąpił zgodnie z instrukcją, a po zapowiedzi Birona, że jego zdaniem caryca zgodzi się na sukcesję saską w Polsce, okazał memoriał Ostermannowi ${ }^{57}$. Na odpowiedź czekano jednak ponad miesiąc. Jak relacjonował Le Fort, Biron miał mu oświadczyć, że należy zacząć konferencje

${ }^{54}$ Poseł miał napisać memoriał jakoby od siebie i zawczasu wysondować, czy zyska on akceptację faworyta. A II do LF, 9 IV 1732, SHAD, Loc. 3024/3, k. 134-147v.

55 „Que le roi mon maître favorisera en toute occasion le gouvernement présent et soutiendra, s'il est nécessaire, de tout son pouvoir, le successeur auquel SM Impériale voudra transmettre la Couronne après elle (ce qu'aucun Piaste ne sauroit faire sans un danger évident de ses propres intérêts) Que de son côté l'Impératrice ne troublera point SM Polonoise dans son Royaume par elle ou par ses alliés. Qu'elle l'assistera au contraire en bon voisin et en fidèle ami et qu'au défaut de SM que Dieu veuille éloigner, la cour de Russie favorisera de touts les moyens permis et utiles, l'élection du Prince Royal son fils, pour son successeur”, „Remarques sur la manière de faire usage de la dépêche instructive [z 9 IV 1732 - U.K.] que le roi envoye au [- - ] Le Fort par courier", SHAD, Loc. 3362/9; por. R. Beyrich, op. cit., s. 4-5.

${ }^{56}$ Zdaniem Beyricha (op. cit., s. 5) z saskich źródeł nie wynika, by August II próbował przeciągnąć Rosję na stronę francusko-polskiego aliansu, jak pisał o tym Droysen, op. cit., t. 4, cz. 3, s. 143.

${ }^{57}$ Kopia dyskursu z Ostermannem z 14 V 1732, SHAD, Loc. 3024/4 (Sachen mit dem Moscowitischen Hofe. Der Geheimer Kriegs Rathe und Envoyé Le Fort Negotiation an denselben. Anno 1732 (VII-XII), vol. XIX), k. 19-22. 
z Ostermannem, ale nie mówić mu o tym, co obiecywano faworytowi. Dawał nadzieje, że caryca zgodzi się na projekt sukcesji na rzecz Fryderyka Augusta i sam obiecywał swe poparcie. Zapewniał też, iż Anna Iwanowna nie ma żadnych zobowiązań sprzecznych z interesem króla polskiego ${ }^{58}$. Wkrótce jednak Biron zaczął się wycofywać, zarzekając, że nie potrzebuje Kurlandii, że wystarczy mu łaska jego pani, a rządzenie zadłużonym księstwem to dlań zbyt wielki ciężar. Następnie stwierdził, iż potrzebowałby 400-500 tys. écus, by uporządkować długi księstwa i móc żyć spokojnie. Było jasne, że faworyt chciał podbić cenę swego poparcia i uzyskać od Drezna znaczną łapówkę. Zapytywał też, jak król polski chciałby zrealizować swe plany: przy pomocy pieniędzy czy wojska. Od razu tė̇ zastrzegał, że on - Biron nie zdecyduje się popierać rozwiązań siłowych. Zdaniem Le Forta oznaczało to, iż należy pospieszyć się z okazywaniem „wdzięczności”, tak by oferta saska nie została przebita przez Prusy czy Austrię ${ }^{59}$. Wówczas z Drezna popłynęły instrukcje, aby poseł spróbował uprościć rokowania i ograniczyć je do dwóch zasadniczych i nierozdzielnych kwestii: aliansu dynastycznego z Rosją i gwarancji sukcesji polskiej dla Wettyna. Deklaracjom Birona o zrzeczeniu się aspiracji do Kurlandii Drezno nie dało oczywiście wiary i wyraziło wkrótce gotowość wypłacenia 500 tys. écus (bądź ekwiwalentu w dobrach ziemskich), ale dopiero gdy rokowania dojdą do skutku ${ }^{60}$.

Ostermann tymczasem przez wiele dni nie składał podobno carycy raportu o treści saskiego memoriału. Podtrzymując nadzieje Le Forta,

${ }^{58}$ LF do A II, 20 V 1733, SHAD, Loc. 3024/3, k. 253-254v; tekst tego raportu znalazł się wśród francuskich relacji z Petersburga wydanych w SIRIO 81, s.328, co każe sądzić, że albo jeszcze w Petersburgu, albo już na dworze saskim potraktowano go jako ostensible i okazano Francuzom; por. R. Beyrich, op. cit., s. 5; E. Rostworowski, op. cit., s. 253.

${ }^{59}$ R. Beyrich, op. cit., s. 6; LF do A II, 3, 10 VI 1733, SHAD, Loc. 3024/3, k. 287-289v, $300 \mathrm{v}$ i 310v-311; , Il s'en est expliqué assez clairement d'autant plus qu'il ne pense pas à la Courlande et que lui peut contribuer en faveur du successeur de ce Duché. Sur qui le roi pourra jeter les yeux, si outre cela on entre dans le projet pour la succession de la Couronne de Pologne et qu'avec cela le mariage ait lieu. Vous jugéz bien Monsieur que à leur sens, ces articles éminents ne sauroient se payer qu'au poids de l'or et que même avant que de parvenir, il faut répandre à me faire que l'on entre en negociation", LF do Thioly'ego, 17 VI 1732, ibidem, k. 236v-237.

60 „Quoique les ordres que je vous ai envoyé s'étendent sur un plan général et sur les vues qui peuvent le limiter. Il ne s'agit pas de faire de chaque point qui y est traité une partie essentielle de la négotiation. Au contraire il faut tâcher de la simplifier et prendre pour but capital le mariage, si la succession y est attachée sans sûreter aux autres qui viendroient d'eux-mêmes à persécution comme accessoires inséparables du premier", A II do LF, 3 VII 1732, SHAD, Loc. 3362/9; por. R. Beyrich, op. cit., s. 6; z relacji Antoine'a Felixa Montiego wynikałoby, że August II obawiał się protestów szlachty kurlandzkiej i gotów był dać ekwiwalent proponowanej sumy w dobrach ziemskich, E. Rostworowski, op. cit., s. 253-254. 
wymawiał się nawałem pracy i odsyłał do Birona. Ten zaś zastrzegał, że jako nie należący do ministerium, nie może dawać wiążących obietnic ${ }^{61}$. Prowadzono więc wobec Sasów typową grę na zwłokę. Odpowiedź w imieniu Anny Iwanowny dano dopiero po miesiącu i była ona wymijająca. Co prawda zadeklarowano chęć bliższego sprzymierzenia się z Augustem II, a nawet poparcia jego zamiarów, zastrzeżono jednak, że kwestia sukcesji w Rosji to sprawa czysto wewnętrzna, do której inne państwa nie powinny się mieszać; w kwestii sukcesji polskiej należy zaś liczyć się ze sprzeciwem Francji i Szwecji. Zaproponowano natomiast własne pośrednictwo w pozyskaniu dla sojuszniczego projektu cesarza ${ }^{62}$. Propozycję aliansu dynastycznego z Saksonią Anna odrzuciła, stwierdzając, że na razie nie będzie wydawać siostrzenicy za mąż. Le Fort uznał tę ostatnią deklarację za schlebiającą, ale złudną ${ }^{63}$, tym bardziej że wkrótce pojawiły się informacje o kolejnej turze małżeńskich rozmów rosyjsko-pruskich w Berlinie ${ }^{64}$. Imperatorowa ustawiła więc Saksonię na miejscu właściwym dla jej potencjału. Uchyliła się od odpowiedzi na propozycje Augusta II, dając mu do zrozumienia, iż nie powinien występować z żadnymi inicjatywami, zwłaszcza dotyczącymi spraw wewnątrzrosyjskich. Biron wprawdzie sugerował, że nie wszystko stracone, że plan małżeński da się przeprowadzić, a 100 tys. rubli dane Ostermannowi może znacznie ułatwić te negocjacje. Dawał do zrozumienia, że wyjazd z Petersburga K.G. Löwenwoldego - głównego przeciwnika porozumienia rosyjsko-saskiego - ułatwi porozumienie. Ostermann i Biron nie byli jednak szczerzy. Wedle ich słów koniuszy miał jechać w sprawach wojskowych do Inflant - w rzeczywistości udawał się na dwór berliński, by prowadzić tam rokowania o alians dynastyczny z Prusami i przyszły traktat „trzech czarnych orłów”65.

${ }^{61}$ LF do A II, 27 V, 3, 10, 17 VI 1732, SHAD, Loc. 3024/3, k. 269 i 299, 309v, 317-317v; z lektury relacji Le Forta $\mathrm{z}$ tego okresu można odnieść wrażenie, że podkanclerzy i faworyt carycy uzgadniali ze sobą stanowiska: Ostermann częściej występował w roli „złego policjanta”, a Biron - „dobrego”. Pierwszy stawiał warunki, określał granice, żądał i odmawiał, drugi - łagodził nastroje, stwarzał nadzieje na kontynuowanie rozmów i możliwość porozumienia się.

62 „Précis du discours que m'a tenu le comte d'Ostermann pour réponse au mien du 14 V 1732", 7/18 VI 1732, SHAD, Loc. 3024/3, k. 334-335v; por. R. Beyrich, op. cit., s. 5; E. Rostworowski, op. cit., s. 254.

${ }^{63}$ Beyrich (op. cit, s. 6) mylił się jednak, twierdząc, iż była to ostateczna odmowa carycy. Bazując na zapewnieniach Birona, że on nie odmawia, Le Fort kontynuował z nim rozmowy, podnosząc walory księcia Sachsen-Weißenfels (doświadczenie wojskowe i wiek jeszcze sprawny), por. LF do A II, 9 i 22 VII 1732, SHAD, Loc. 3024/4, k. 13, 69v-70.

${ }^{64}$ LF do A II, 19 i 22 VII, SHAD, Loc. 3024/4, k. 59 i 63v.

${ }^{65}$ R. Beyrich, op. cit., s. 6 (na podstawie LF do A II, 22 VII 1732, SHAD, Loc. 3024/4, k. 69v i 70-70v); J. G. Droysen, op. cit., t. 4, cz. 3. s. 144-145. 
Drezno słusznie uznało, że raporty Le Forta każą powątpiewać w dobre intencje Rosjan ${ }^{66}$. Saski poseł, zaniepokojony brakiem reakcji, słał w sierpniu ciągłe zapytania, dlaczego dwór nie okazuje odpowiedniego zainteresowania sprawą i nie daje pieniędzy ${ }^{67}$. Wewnętrzny saski memoriał „Sur la negotiation avec la Russie” stwierdzał jednak brutalnie, że mimo wszystkich nadziei, jakie strona rosyjska dała Le Fortowi, liczne punkty kazały powątpiewać w szczerość Ostermanna, od dawna przekupionego przez stronę przeciwną. Nie można też było odpowiedzieć satysfakcjonująco dla Rosjan bez zbytniego odkrycia się, ani polegać za bardzo na „ekonomii” Le Forta czy liczyć na jego wnikliwość $\mathrm{i}$ bystrość w dystrybucji ewentualnie posłanych pieniędzy. Z tego powodu należało raczej zaproponować Rosjanom wysłanie na dwór polski osoby zaufania („personne de confiance”), by przystąpić na poważnie do negocjacji małżeńskich pod nadzorem bardziej doświadczonych ministrów saskich i samego króla. Na wniosek Augusta II postanowiono napisać do Birona i Ostermanna listy konfidencjonalne, aby potwierdzić to, co przekazał im Le Fort, i uzyskać przeniesienie negocjacji na grunt polski lub saski ${ }^{68}$. August II stwierdził jednak, że póki Anna Iwanowna nie poda własnych warunków, nie powinna oczekiwać bliższych wyjaśnień od króla polskiego. Nie powinna też spodziewać się dobrego przyjęcia przez naród polski małżeństwa Anny Leopoldowny z księciem pruskim $^{69}$.

Kolejne miesiące 1732 r. nie przyniosły postępów w petersburskich negocjacjach. Le Fort cały czas dawał się łudzić Bironowi i Ostermannowi. Usilnie, acz bezskutecznie doszukiwał się też oznak rychłego upadku Löwenwoldów i partii pruskiej, a wszystko to w czasie, gdy w Berlinie K.G. Löwenwolde finalizował sojusz trzech czarnych orłów ${ }^{70}$. W Dreźnie alians ten określono jako „chorobę, na którą niemal nie ma lekarstwa"71.

${ }^{66}$ A II do LF, 10 VII 1732 (ekspedycja 12 lipca), SHAD, Loc. 3362/9.

${ }^{67}$ LF do A II, 5 i 19 VIII 1732, SHAD, Loc. 3024/4, k. 90-90v, 94v-95.

68 „Sur la négociation avec la Russie”, [przed 4 IX 1732],SHAD, Loc. 3024/4,k. 102-103.

${ }^{69}$ R. Beyrich, op. cit., s. 6; „Le ministère de Russie pouvant aisément juger que si la princesse Anne passoit dans une autre maison et particulièrement dans celle de la Prusse, il ne seroit point de traitté qui put calmer la jalousie que la nation polonoise en concouroit, qui put engager la maison de Saxe à seconder les suites d'une telle alliance", A II do LF, 4 IX 1732, SHAD, Loc. 3362/9. Liczne zwroty z tej instrukcji zostały następnie powielone w listach niemieckich do Birona i Ostermanna, 4 IX 1732, minuty w SHAD, Loc. 3024/4, k. 106-106v i 111-111v, 113; odpowiedzi z komplementami z 12 X 1732, ibidem, k. 107-107v, 110 i 112-113.

${ }^{70}$ R. Beyrich, op. cit., s. 6; LF do AII, 4 i 25 X 1732, SHAD, Loc. 3024/4, k. 189.

${ }^{71}$ „Il n'y a aucun lieu de douter que le sûret evanté sur les ministres de Vienne et de Berlin peut presque deviner sur les moindres indices [--] Ce qui me paroît un mal 
Co więcej, Sasi otrzymali przeciek z Berlina, że Prusacy wiedzieli już o ich ofercie pół miliona écus dla Birona, co kazało się spodziewać, że faworyt może zostać „podkupiony” przez stronę przeciwną ${ }^{72}$.

W listopadzie 1732 r. Le Fort poinformował Augusta II, że Biron ponownie podjął w rozmowie z nim kwestię sukcesyjną. Faworyt oświadczył, iż wie, że za staraniami króla polskiego o układ dynastyczny z Rosją kryje się sprawa sukcesji polskiej ${ }^{73}$. Następnie miał wyrazić przekonanie, że można zrealizować ten „wielki projekt” i doprowadzić do wyboru elektorowicza, jednak sprawa takiej wagi wymaga włączenia do niej trzeciego uczestnika. Nawiązując do wcześniejszych propozycji Ostermanna, zaproponował wówczas rozpoczęcie przy rosyjskim pośrednictwie negocjacji z Wiedniem ${ }^{74}$. Zasugerował, aby wykorzystać we wzajemnych kontaktach jako osobę zaufaną żonę posła - panią Le Fort, używaną już wcześniej w poufnych misjach ${ }^{75}$. Obiecał, że przekaże się jej instrukcje preliminaryjne z zadaniem wysondowania możliwości rozpoczęcia oficjalnych rokowań. Biron dał więc Le Fortowi nadzieję na ruszenie z martwego punktu (łechcąc pewnie poselskie ego obietnicą powierzenia ważnej misji jego żonie $)^{76}$. Zarazem Petersburg zyskał pretekst do kolejnej zwłoki - konieczność oczekiwania na decyzję Drezna. Rzeczywiście, do końca 1732 r. nic nowego w sprawie się nie zdarzyło.

Jeszcze w styczniu 1733 r. Biron uparcie twierdził, że popiera saskie plany. Rozmowy prowadzono zwodząc i wysuwając kolejne obiekcje, zo-

presque sans remède dans des affaires qui demandent tant de sûret et de ménager", A II do LF, 15 XI 1732, SHAD, Loc. 3362/9.

72 Brühl do LF, 9 X 1732, SHAD, Loc. 3024/4, k. 133; A II do LF, 16 XII 1732, SHAD, Loc. 3362/9; rzeczywiście Prusacy przedstawili wkrótce Bironowi ofertę 200 tys. guldenów, jeśli odstąpi Kurlandię księciu pruskiemu, Fryderyk Wilhelm I do Birona, 11 XII 1732, V. Ger'e, op. cit., aneks, s. 1-2; z kolei Austriacy obiecywali faworytowi dobra na Śląsku należące onegdaj do Aleksandra Mienszykowa (Aleksandr Danilovič Menšikov) i tytuł księcia Rzeszy, SIRIO 66, s. 508.

${ }^{73}$ „un traitté d'alliance successif qui assure la succession à la Couronne pour le Prince Royal", LF do A II, 18 XI 1732, SHAD, Loc. 3024/4, k. 225.

${ }^{74}$ LF do A II, 18 XI 1732, SHAD, Loc. 3024/4, k. 225-225v, 226v-227. O konieczności pogodzenia się dworu saskiego z cesarzem jako warunku sine qua non rozmów z Rosją wspominał też Rondeau 18/29 XI 1732, SIRIO 66, s. 531.

${ }^{75} \mathrm{O}$ udziale pani Le Fortowej w planach ożenienia Augusta II z Anną Iwanowną SIRIO 81, s. 175, 322 i SIRIO 66, s. 310. Żona posła była też w latach 1725-1726 zaangażowana - może nawet jako inicjatorka - w inny projekt dynastyczny (,projet de deux dames") ożenienia Maurycego Saskiego z carówną Elżbietą Piotrowną, U. Kosińska, August II w poszukiwaniu sojusznika, s. 459-461, 470.

${ }^{76}$ LF do A II, 18 XI 1732, SHAD, Loc. 3024/4, k. 227-228; Ostermann potwierdził słowa Birona, choć nieco „mniej otwarcie”, k. 229-229v; R. Beyrich, op. cit., s. 8 (na podstawie A II do LF, 16 XII 1732), błędnie twierdził, że pani Le Fort miała jechać do Augusta II, aby zakończyć rokowania z dworem saskim - mowa była jednak tylko o preliminariach. 
stawiając jednak cały czas drzwi do rokowań zachęcająco uchylone ${ }^{77}$. Wyjazd pani Le Fort wciąż się odwlekał ${ }^{78}$. Wydaje się też, że cały czas czekano na jakieś niedyskrecje ze strony jej męża, np. na otwarte przyznanie, że Saksonia oczekuje pomocy wojskowej dla osadzenia elektorowicza na tronie polskim ${ }^{79}$. Przy okazji Biron upomniał się o zwiększenie wynagrodzenia dla Ostermanna i dodanie do obiecanych 100 tys. rubli za zgodę na plan małżeński, 200 tys. talarów za włączenie do traktatu artykułu o poparciu kandydatury saskiej w Polsce ${ }^{80}$.

W końcu stycznia 1733 r., gdy K. G. Löwenwolde wrócił z Berlina z podpisanym traktatem „trzech czarnych orłów”, Biron i Ostermann nagle oziębli. 7 lutego $1733 \mathrm{r}$. żona Le Forta w nadziei otrzymania instrukcji do rokowań z Augustem ponowiła wcześniejsze propozycje saskie. O śmierci króla polskiego jeszcze w Petersburgu nie wiedziano, ale już wówczas odpowiedziano odmownie na wszystkie punkty memoriału z maja ub.r., podnosząc przy tym liczne, wielokrotnie używane jako pretekst do udzielania odmownych odpowiedzi czy kontrolowanego oziębiania stosunków, kwestie sporne z Rzecząpospolitą, takie jak: rokowania polsko-szwedzkie bez

${ }^{77}$ LF do A II, 6 I 1733, SHAD, Loc. 3024/5 (Sachen mit dem moscovitischen Hofe. Le Fort Negotiation, Ao 1733, vol. XX), k. 3v-4; nie jest prawdą, że Ostermann całkowicie odmówił wówczas wchodzenia w sojusz rosyjsko-saski, LF do A II, 6 I 1733, SHAD, Loc. 3024/5.

${ }^{78}$ O planowanym, a wciąż niezrealizowanym wyjeździe donosili na przełomie stycznia-lutego 1733 r. posłowie angielski i francuski, SIRIO 66, s. 457-458 i SIRIO 81, s. 528.

79 „L'on fit entrevoir sur quel pied l'on pense que l'affaire de la succession dut être traitée, que la Russie ne peut s'engager de forcer l'élection que par main armée et qu'un corps de 60 à 70 mille hommes fera plus que tous les millions que l'on rependra près des Polonois, dont la plupart tourneront casaque et prendront de tous côtés sans prendre aucun parti qu'il est différent des familles, dont VM peut être entièrement assurée, mais que d'une façon ou d'autre il paroît indispensable que cette négociation doive être brusquée sans donner le temps aux autres puissances, ni aux Polonois de s'apercevoir de nâitre démarches", LF do A II, 27 I 1733, SHAD, Loc. 3024/5, k. 19v; por. R. Beyrich, op. cit., s. 7-8.

${ }^{80}$ „que pour cet effet il paroît que je ne saurois mieux faire que de lui [Ostermann] faire entrevoir un ordre de VM par lequel elle me charge d'insister près de lui pour qu'il facilite à accélérer nos négociations et traiter délai et de lui promettre que si le traité de la succession a lieu, que VM tient à sa disposition 200000 écus indépendamment des 100000 roubles pour le mariage [- - Vous pouvez lui déclarer que si l'article de la succession a lieu, je tiendrai à sa disposition deux cent mille écus en reconnaissance de ses peines et de l'amitié qu'il a témoigné indépendamment des cent mille que vous lui avez offert si le mariage réussit. Mais vous devez exiger de lui un secret inviolable, puisque c'est une affaire entre lui et moi, qui ne va pas contre les intérêts de sa souveraine". LF do A II, 27 I 1733, SHAD, Loc. 3024/5, k. 18v-19v, 23-23v; por. R. Beyrich, op. cit., s. 8; Beyrich myli się, że pieniądze przekazano; Le Fort - za radą Birona - proponował dopiero, aby obiecać, że jak traktat dojdzie do skutku, to Ostermann dostanie 200 tys. + 100 tys., by przeważyć wpływy i korupcję Prusaków. 
mediacji rosyjskiej, uciemiężenie Kościoła prawosławnego w Rzeczypospolitej, opresje poddanych rosyjskich na terytoriach pogranicznych itp. Chyba jedynie dla upozorowania, iż nie jest to ostateczna odmowa, zapowiedziano, że jeśli August II zechce odnowić przyjaźń z cesarzem, Rosja gotowa jest w tym pośredniczyćc1 ${ }^{81}$. Wkrótce, tj. w nocy z 12 na 13 lutego 1733 r., do Petersburga przybył kurier z Warszawy z informacją o śmierci Augusta II ${ }^{82}$. Rozwiewało to ostatecznie nadzieje na przeprowadzenie sojuszu sasko-rosyjskiego w kształcie proponowanym przez Drezno.

Na zakończenie warto postawić kilka pytań dotyczących celów polityki dworu sasko-polskiego wobec Rosji i oceny stanu wzajemnych stosunków w latach 1730-pocz. 1733. Dzielą się one na trzy podokresy. Pierwszy trwał od lutego do sierpnia 1730 r. i był kontynuacją dotychczasowego kursu utrzymania poprawnych stosunków z Rosją. Próbowano wówczas pozyskać przychylność nowej carycy za pośrednictwem osób z kręgu tzw. fakcji staroruskiej. Okres drugi, od września 1730 do grudnia 1731 r., charakteryzował się znacznym ochłodzeniem kontaktów i przekonaniem dworu saskiego o braku podstaw do jakiejkolwiek współpracy. Drezno postawiło wówczas na negocjacje z Francją, z kolei Rosja zaczęła zacieśniać stosunki z Austrią i Prusami. Okres trzeci, od końca 1731 r. do śmierci Augusta II, to próba przywrócenia dobrych stosunków z Rosją poprzez renegocjowanie z nią układu o przyjaźni na saskich warunkach, a zarazem rozerwania zawiązującego się sojuszu trzech czarnych orłów. Wynikało to z przekonania, że związek wszystkich trzech sąsiadów Rzeczypospolitej stanowić będzie główną przeszkodę do przeprowadzenia saskiej sukcesji w Polsce. Uzyskanie rosyjskiej gwarancji dla tej sukcesji było celem jasno wyartykułowanym. Analiza korespondencji Le Forta pokazuje, że dla uzyskania owej gwarancji Drezno, poza znaczną kwotą pieniędzy, gotowe było zaofiarować Kurlandię - lenno, nad którym od lat nie miano pełnej kontroli i które już wcześniej bywało argumentem przetargowym w rozlicznych saskich kalkulacjach. Uderza jednak ówczesna słabość saskiej dyplomacji. Widać nie tylko brak głębszej koncepcji, która wychodziłaby poza wąsko rozumiany interes dynastyczny, ale też niedostatek środków i wykwalifikowanych dyplomatów, niezbędnych

${ }^{81}$ Podobny zestaw pretensji wobec Polski pojawił się m.in. w rozmowie Burkharda Christopha Münnicha z francuskim chargé d'affaires Magnanem, G. A. Nekrasov, op. cit., s. 205; próbując się dowiedzieć od Birona czegoś o motywach odmowy, Le Fort uzyskał jedynie mało wiarygodną informację, że powodem ochłodzenia są wieści z Porty o jakoby polskim podjudzaniu jej przeciw Rosji, LF do A II, 10 II 1733, SHAD, Loc. 3024/5, k. 32-34v.

${ }^{82}$ Relacja Rondeau z 3/14 II 1733, SIRIO 66, s. 555; Magnan datuje wiadomość dopiero na 13 lutego wieczorem, SIRIO 81, s. 536. 
do realizacji ambitnych celów politycznych. Próba działania przez intrygi dworskie i za pośrednictwem stosunkowo niskiego rangą dyplomaty, jakim był Le Fort (o jego żonie nie wspominając), okazała się nieskuteczna. Austria i Prusy przebijały Saksonię i w propozycjach sojuszniczych, i korupcyjnych. Starzejący się i schorowany „saski Machiawel”, bez sojuszników w Europie, otoczony wrogami w Polsce, poza Kurlandią nie mógł niczego cennego Rosji zaproponować i w żaden sposób nie był w stanie jej zagrozić. Trzeba też pamiętać, że w omówionych negocjacjach reprezentował nie Rzeczpospolitą, ale interesy własnego rodu. Polska, jej lenno i jej korona były dlań jedynie przedmiotem targów.

Należy też zauważyć, że mimo fiaska negocjacji sasko-rosyjskich w ostatnich latach panowania Augusta II, jeszcze przed śmiercią króla popłynął do Petersburga wyraźny sygnał, jaką cenę gotów jest zapłacić dwór saski za uzyskanie rosyjskiej zgody na wettyńską sukcesję w Polsce. Bardzo możliwe, że rozmowy z 1732 r., a zwłaszcza obietnica przekazania Kurlandii Bironowi, wywarły pewien wpływ na to, że po śmierci Augusta II Rosja stosunkowo łatwo zrezygnowała nie tylko z zapisanej w traktacie Löwenwoldego kandydatury księcia Emanuela Portugalskiego do tronu polskiego, ale dość szybko poparła opcję wsparcia saskich starań o tron polski ${ }^{83}$.

\section{The Relations of Augustus II and Russia in 1730-early 1733 in the Light of an Account by Jean Le Fort, the Saxon Legate in Moscow and St. Petersburg}

The author presents how in the wake of the reign of the underage Peter II, barren from the viewpoint of Polish-Russian relations, Augustus II started to seek allies at the Russian court the moment Anna Ivanovna ascended the throne of the tsars was mounted. Upon the basis of the diplomatic correspondence of the

${ }^{83}$ Wbrew obiegowym przekonaniom traktat Löwenwoldego nie zamykał Wettynowi drogi do polskiego tronu. Artykuł tajny o poparciu kandydatury Emanuela Portugalskiego zastrzegał, że gdyby ustalony przez sąsiadów kandydat umarł, albo okazało się, że nie da się przeprowadzić jego elekcji, sygnatariusze zawczasu porozumieją się, by wybrać inną odpowiednią osobę. W całym traktacie jedyną osobą explicite wykluczoną był Stanisław Leszczyński, por. Preussens Staatsverträge, t. 87, s. 429-440; Sobranie traktatov, t. 1: Traktaty s Avstrej. 1648-1762, S. Peterburg 1874, s. 311-324; jako pierwszy zwrócił na to uwagę Jerzy Dygdała, Gra pozorów: zabiegi dyplomacji cesarskiej o rosyjską interwencję zbrojna w Rzeczypospolitej w 1733 r., w: W cieniu wojen i rozbiorów. Studia z dziejów Rzeczypospolitej XVIII i początków XIX wieku, red. U. Kosińska, D. Dukwicz, A. Danilczyk, Warszawa 2014, s. 140; sondaże Rosji (najpóźniej w połowie marca 1733 r.) o możliwości poparcia Wettyna przez cesarza wspominał m.in. Max. Braubach, Prinz Eugen von Savoyen. Eine Biographie, Wien 1965, t. 4, s. 235-236 i 439 przyp. 120. 
Saxon legate in St. Petersburg - Jean Le Fort - U. Kosińska demonstrates that originally Dresden placed its hopes in the so-called old Russian faction. After the latter's fall it sought possibilities for gaining influence upon the tsarina via the intermediary of her favourite, Ernst Johann Biron. The danger of closer Russian-Prussian and Russian-Austrian relations was rapidly noticed. Saxon proposals aimed, on the one hand, at splitting the emergent alliance of the three black eagles, and, on the other hand, at obtaining for the Wettin dynasty a Russian promise to support succession to the Polish throne. The price, which Augustus II was already then willing to pay was Courland, offered to Biron. Quite possibly, the talks held in 1732, despite their ultimate fiasco, exerted a certain impact upon the fact that after the death of Augustus II Russia relatively easily resigned from the candidature of Prince Emmanuel of Portugal to the Polish throne, mentioned in the Löwenwolde treaty, and rather swiftly supported Saxon endeavours focused on winning the Polish crown.

Translated by Aleksandra Rodzińska-Chojnowska 